\title{
Mass Factory Housing: Design and Social Reform Fani Kostourou
}

1 See, e.g., Ray Forrest, "The Meaning of Homeownership," Environment and Planning D: Society and Space 1, no. 2 (1983): 205-16; Richard Ronald, The Ideology of Home Ownership: Homeowner Societies and the Role of Housing (Basingstoke: Palgrave Macmillan, 2008); and Nicholas Bullock and James Read, The Movement for Housing Reform in Germany and France, 1840-1914 (Cambridge: Cambridge University Press, 1985).

2 See, e.g., Alice Coleman, Utopia on Trial: Vision and Reality in Planned Housing (London: Hilary Shipman Ltd, 1985); Bill Hillier, "Against Enclosure," in Rehumanizing Housing, eds. Necdet Teymur, Thomas A. Markus, and Tom Woolley (London: Butterworths, 1988): 63-88; Hayley A. Rowe, "The Rise and Fall of Modernist Architecture," Inquiries Journal/Student Pulse 3, no. 4 (2011), http:// www.inquiriesjournal.com/a?id=1687 (accessed June 8, 2018); Julienne Hanson and Bill Hillier, "The Architecture of Community: Some New Proposals on the Social Consequences of Architectural and Planning Decisions," Architecture et Comportement/Architecture and Behaviour 3, no. 3 (1987): 251-73; and Paul Spicker, "Poverty and Depressed Estates: A Critique of Utopia on Trial," Housing Studies 2, no. 4 (1987): 283-92.

3 Kathleen Scanlon, Melissa Fernández Arrigoitia, and Christine M. E. Whitehead, "Social Housing in Europe," European Policy Analysis 17 (2015): 1-12.

4 See, e.g., Ray Forrest and Yosuke Hirayama, "The Financialisation of the Social Project: Embedded Liberalism, Neoliberalism and Home Ownership," Urban Studies 52, no. 2 (2015): 233-44; Marc Angélil and Cary Siress, "House of Cards," Open City (2009): 131-40; Manuel B. Aalbers, "The Financialization of Home and the Mortgage Market

https://doi.org/10.1162/desi_a_00567
During the nineteenth century, ideas about housing reform were prevailing in Europe. Housing and home ownership were

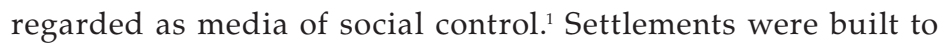
provide workers with better living conditions and alleviate the tensions between employers and employees. A century later, Modernism followed suit, offering yet another way of engineering society through housing. As a response to urban population growth and slum clearance, architects envisioned ways to accommodate the masses based on ideals of communal living. Failing to deliver their social promises, the new designs-alongside problems in planning, maintenance, and administration-stigmatized mass public housing. ${ }^{2}$

Today, the economic crisis, immigration, and displacement of refugees have once again intensified the entanglement between housing, design, and society. Despite the acute housing deficit, large estates are being demolished, and affordable housing is moving out of public control. ${ }^{3}$ Meanwhile, major housing programs subsidize poorly designed homes for disadvantaged households while feeding the real estate debt. ${ }^{4}$ These realities signal another restructuring of society via housing, but this time, they question the ideals of home ownership and its financialization.

This article explores working-class housing and the ways it has been used as an instrument for social reform in the past. It looks at the socio-political agenda behind the birth of company towns, and the role of architecture and urban design in shaping the social life of the inhabitants. The study takes as an example Cité Ouvrière in Mulhouse (France), a nineteenth-century factory settlement that provided workers with subsidized access to property. Through analysis of municipal archival sources and other literature, it traces the incremental transformation of a uniform mass factory housing scheme into an ethnically diverse and formally heterogeneous city quarter (Figure 1). The article concludes that what started as a medium of social control has evolved into an active form of spatial agency, which manifests itself in the physical adaptations of individual houses. The findings provide valuable insight into the relationship between design and social form, and into the latent possibilities of mass housing and home ownership to offer a viable answer to the current housing question. 

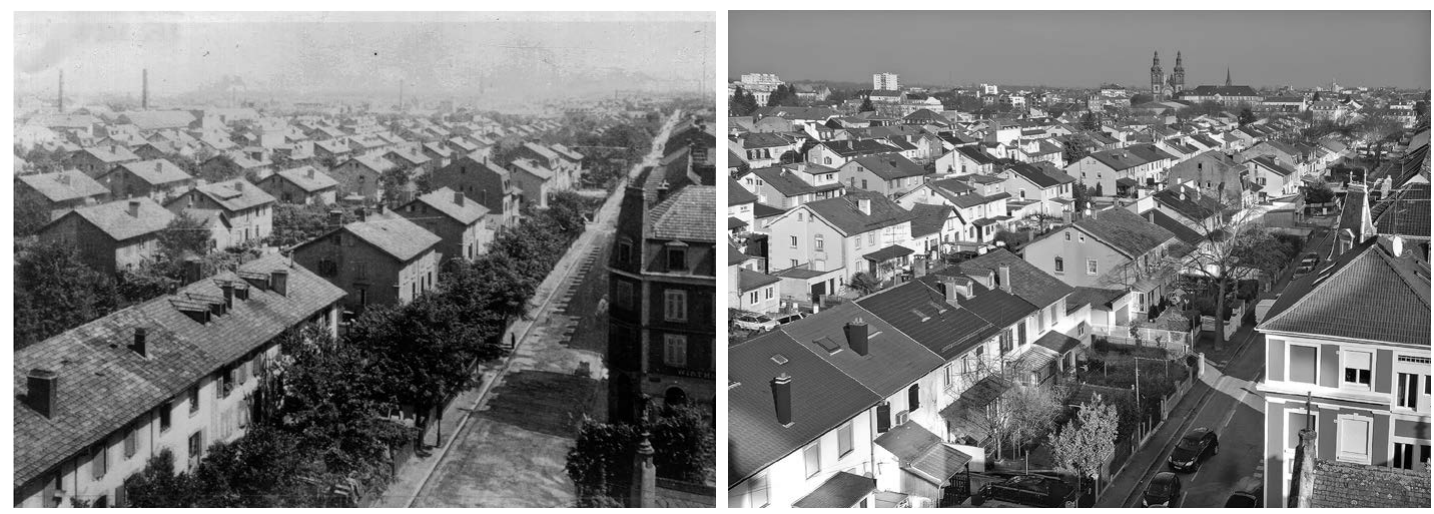

Figure 1

Aerial view of Cité Ouvrière and Strasbourg street in 1908 (left) and 2017 (right), photographed using the same vantage point. Sources: (left) Archives de Mulhouse, (right) Luc Georges, edited by Fani Kostourou.
Crisis," in The Financialization of Housing: A Political Economy Approach (Abingdon: Routledge, 2016), 40-63.

5 Marcel Smets, L'avènement de la citéjardin en Belgique: histoire de l'habitat social en Belgique de 1830 à 1930 [The advent of the garden city in Belgium: history of social housing in Belgium from 1830 to 1930] (Brussels: Editions Mardaga, 1977)

6 See, e.g., Sybella Gurney, “Housing Reform," Charity Organisation Review, New Series 21, no. 123 (1907): 131-40; C. Osborn, "Housing Reform in Scotland," Charity Organisation Review, New Series 43, no. 255 (1918): 93-104; “Housing Reform," The British Medical Journal 1, no. 2733 (1913): 1075-76, http://www. jstor.org/stable/25301536 laccessed June 08, 2018); and "Housing Reform in Germany," The British Medical Journal2, no. 2336 (1905): 891-92, http://www. jstor.org/stable/20286888 (accessed June 8, 2018)

\section{The Emergence of Company Towns}

By the end of the nineteenth century and the beginning of the twentieth, a general concern arose in Europe regarding the living conditions of the working class. A systematic survey in 1838 in Brussels drew the entire continent's attention to the housing question. ${ }^{5}$ Journals of the time, such as the Charity Organisation Review and British Medical Journal, discussed the congestion of populations in industrial areas and the absence of adequate or proper housing. ${ }^{6}$ In France, workers "mingled indiscriminately in cramped quarters, beds were shared, and the numbers of cabarets and wine shops in each block continued to grow."7 Due to the overcrowding, epidemic diseases like tuberculosis spread, resulting in high rates of mortality. ${ }^{8}$

For the middle class (bourgeoisie) and public health activists, the root of the problem was the poor quality of housing. Housing was to blame for pushing workers to the margins of the contemporary society, and for the resulting excessive drinking, delinquency, and prostitution. Against this background, the Metropolitan Association for Improving the Dwellings of the Industrious Classes (MAIDIC) and the Society for Improving the Conditions of the Labouring Classes (SICLC) were founded in Britain in 1841 and 1844, respectively. ${ }^{9}$ They helped to promote the reformist agenda, which primarily sought to provide workers with improved homes and to assimilate them progressively into the middle class (embourgeoisement). ${ }^{10}$ By that time, the reform rhetoric had already gained momentum, which culminated later in the passing of the 1850 Melun Law on unsanitary housing in France, and the 1851 Great Exhibition of the Works of Industry of All Nations in London."

The systematic response to these challenges came with the introduction of mass factory housing in the second half of the nineteenth century. Company towns were built next to factories to reduce the commuting time of the workforce and to increase 
7 Ann-Louise Shapiro, "Housing Reform in Paris: Social Space and Social Control," French Historical Studies 12, no. 4 (Durham, NC: Duke University Press, 1982), 488.

8 Emile Trélat, "Cités Ouvrières, Maisons Ouvrières," [Company Towns, Industrial Houses] in Exposition Universelle Internationale de 1878 À Paris: Comptes-Rendus Sténographiques, Tome / [International Universal Exhibition of 1878 in Paris: Stenographic Transcripts, Vol. I] (Paris: Organisation Du Congrès, 1880): 538-52.

9 John Nelson Tarn, Five Percent Philanthropy: An Account of Housing in Urban Areas Between 1840 and 1914 (Cambridge: Cambridge University Press, 1973).

10 John Goldthorpe, David Lockwood, Franck Beckhofer, and Jennifer Platt, The Affluent Worker, Vols. 1-3 (Cambridge: Cambridge Press, 1968).

11 Will Clement, "The 'Unrealizable Chimera': Workers' Housing in NineteenthCentury Mulhouse," French History 32 , no. 1 (2018): 74; and Stéphane Jonas, Mulhouse et ses cités ouvrières: perspective historique, 1840-1918: quatrevingts ans d'histoire urbaine et sociale du logement ouvrier d'origine industrielle [Mulhouse and its company towns: historical perspective, 1840-1918: eighty years of urban and social history of working-class housing of industrial origin] (Strasbourg: Oberlin, 2003), 25.

12 In Europe, company towns were built in Britain (towns like Port Sunlight and Bournville were regarded as models for the Garden City movement), Germany (influencing its modern urban planning), Belgium, France, and Spain, among others. For a more detailed discussion on these towns, see, e.g., John S. Garner, The Company Town: Architecture and Society in the Early Industrial Age (New York: Oxford University Press, 1992); Michael Honhart, "Company Housing As Urban Planning in Germany, 1870-1940," Central European History 23, no. 1 (1990): 3-21; and John Douglas Porteous, "The Nature of the Company Town," Transactions of the Institute of British Geographers 51 (1970): 127-42.

13 R. J. Harrison Church, "The Firestone Rubber Plantations in Liberia," Geography 54, no. 4 (1969): 430; and Porteous, "The Nature of the Company Town," 128. the production rates. They differed in size, layout, and purpose, depending on their context, ${ }^{12}$ however, they often shared common characteristics. ${ }^{13}$ Specifically, from an operational point of view, they were funded, constructed, and managed by industries, providing subsidized home ownership, social hierarchy, economic and political control, and advanced infrastructure. In addition, from a morphological perspective, they were large-scale, lowdensity, territorially bounded, built on remote locations in the city periphery, and characterized by architectural standardization. In fact, Porteous describes them as "a sea of housing peculiar both for its uniformity of style and for its obvious contemporaneous character." ${ }^{\prime 14}$

Company towns were designed to create local neighborhoods and a sense of community among workers and inhabitants. Spencer and Pahl found that social networks and community attachment can be rooted in particular locales, especially for people who have not been geographically mobile or have been uprooted and have had to start afresh in a new area. ${ }^{15}$ Henning and Lieberg also observed that local neighboring has a great influence on the social life of blue-collar workers. ${ }^{16}$ And Gans discussed how built homogeneity of suburban Levittown was used as a "means for creating a unity and cohesion that did not exist in the social system. ${ }^{\prime 17}$ In the case of company towns, urban and architectural design were deliberately conceived to shape a social future. The uniform aspect of their design was meant to "induce a feeling of unity under one command." ${ }^{\prime 18}$ Admittedly, this intent might have worked well on the small scale, fostering "a greater sense of community," but it also "insulate[d] their employees from the influences of a larger urban community." ${ }^{\prime 19}$

\section{Social Reform Follows Housing}

Indeed, despite their noble cause, company towns were political and economic measures to remedy the social and moral state of the working class. New housing aimed to alleviate the tension between the employees and the employers, to silence the syndicalism and unionism, and to discourage potential strikers. This paternalistic character is pointed out by Malon, who argued that paying off a fifteen- to twenty-year mortgage prevented workers from going on a strike. ${ }^{20}$ In fact, employed workers tied to mortgage and property were the least likely to get involved in radical activities. ${ }^{21}$

The second objective was social control. Both employment and housing were becoming dependent on the discretion of the industrialists. Turot and Bellamy explain that workers living in company houses and paying rent to their employer were 
Figure 2

Perspective view of the first development phase of Cité Ouvrière in Mulhouse. Drawing by Lancelot. Source: Archives de Mulhouse.
14 Porteous, "The Nature of the Company Town," 133.

15 Liz Spencer and Ray Pahl, Rethinking Friendship: Hidden Solidarities Today (Princeton, NJ: Princeton University Press, 2006), 194.

16 Cecilia Henning and Mats Lieberg, "Strong Ties or Weak Ties? Neighbourhood Networks in a New Perspective," Scandinavian Housing and Planning Research 13, no. 1 (1996): 22.

17 Herbert J. Gans, The Levittowners: Ways of Life and Politics in a New Suburban Community (New York: Pantheon, 1967), 146.

18 Porteous, "The Nature of the Company Town," 135

19 Honhart, "Company Housing," 20.

20 Benoît Malon, Le Socialisme Intégral: 2e Partie, Des Réformes Possibles et Des Moyens Pratiques [Integral Socialism: Part II, Possible Reforms and Practical Means] (Paris: F. Alcan, 1894), 388.

21 See, e.g., Shapiro, "Housing Reform in Paris," 498; and Richard Harris, "Industrial City," in International Encyclopedia of Human Geography, eds. Rob Kitchin and Nigel Thrift (Oxford: Elsevier, 2009), 384.

22 Henri Turot and Henry Bellamy, "Le Surpeuplement et Les Habitations À Bon Marché" [Overcrowding and Low-Cost Housing] (Paris: F. Alcan, 1907), 27-8.

23 Honhart, "Company Housing," 17-8.

24 Jules Simon, "Sociétés Coopératives de Constructions de Logements" [Cooperative Housing Development Societies] Séances et Travaux de I'Académie Des Sciences Morales et Politiques [Sessions and Works of the Academy of Moral and Political Sciences ] 75 (1866): 260-63; and Goldthorpe et al., “The Affluent Worker."

25 Ann-Louise Shapiro, Housing the Poor of Paris, 1850-1902 (Madison, WI: University of Wisconsin Press, 1985), 92.

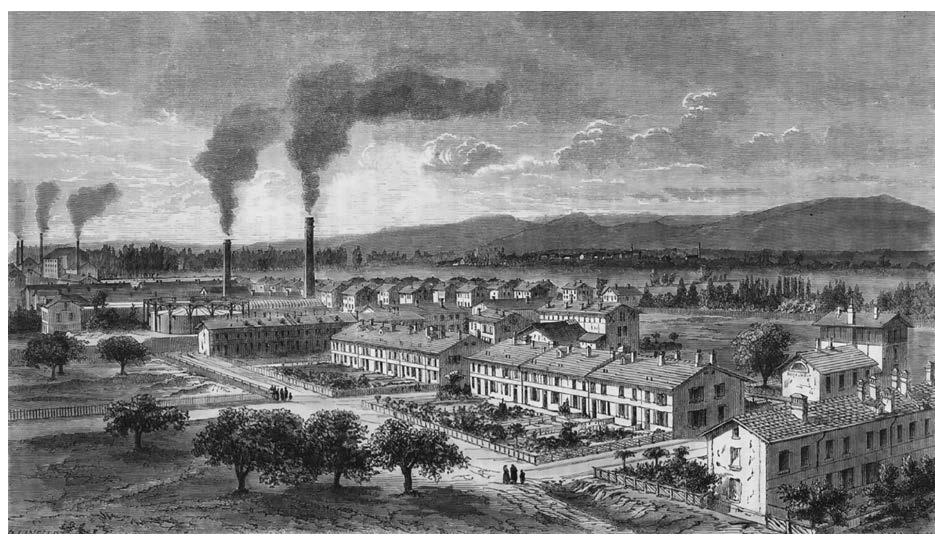

automatically placed in an "inferior bargaining position" regarding their working rights. ${ }^{22}$ Employers had the power to alter and implement restrictions on the number of lodgers, the occupation of children, or the period of residence, following employees' changes of employment or participation in unwanted political acts. ${ }^{23}$

The implications of social reform became further evident with the provision of home ownership, which targeted the social and moral transformation of workers. On the one hand, the bourgeoisie aspired to initiate workers into middle-class ways-for instance, regarding the consumption of goods, including housing. ${ }^{24}$ On the other hand, they wanted to turn every worker "from an uprooted nomad to a settled petty proprietor." ${ }^{25}$ By providing a house with a garden, the industrialists could tie workers down to one place and worksite. ${ }^{26}$

Ultimately, the haute bourgeoisie believed that moral reform would inevitably follow domestic reform. ${ }^{27}$ In 1882 Demolins, editor-in-chief of La Réforme Sociale [Social Reform], wrote: "The possession of his home creates in him [the worker] a complete transformation.... With his own small home and garden, the worker becomes the head of his family, worthy of this name. He is moral and provident, aware of his roots, and exercises authority over his family. He soon forgets the cabaret whose main appeal has been to remove him from his miserable hovel.... It is therefore of immense social importance for the worker to possess his own home. Soon it is his home which possesses him; it gives him morals, it establishes him, it transforms him. ${ }^{\prime 28}$ Similarly, Ambjornsson used the term "skötsamhet" [well-behaved] to describe the controlled and conscious life of a Swedish worker, and Jonas referred to the reformed worker as an "ouvrier rangé," [orderly worker] to indicate a wellbehaved and disciplined family man..$^{29}$

\section{The Exemplary "Cité Ouvrière"}

In France, "cités ouvrières" [working-class settlements-similar to company towns] were first introduced by Napoleon III in 1848 but grew in popularity after the 1880 s. Napoleon sponsored housing to 


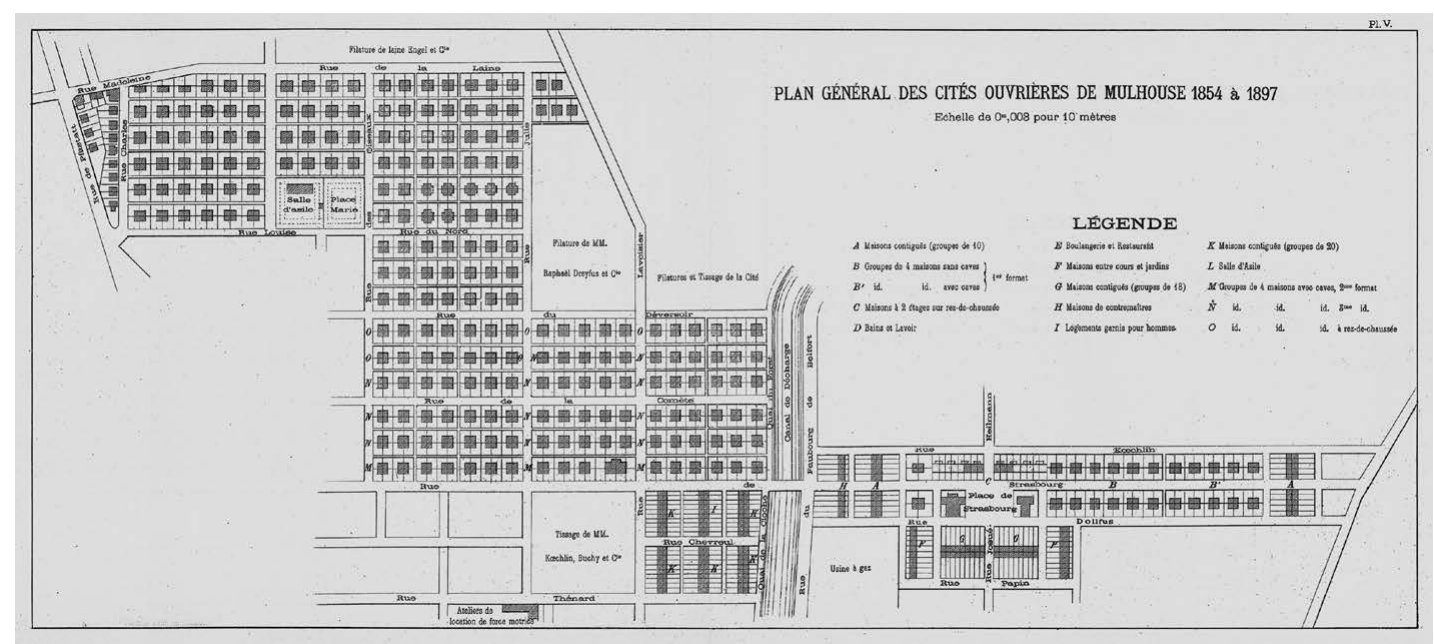

Figure 3

General plan of Cité Ouvrière in Mulhouse from 1853 to 1897. Source: Archives de Mulhouse.

26 Harold Bellman, The Building Society Movement (London: Methuen, 1927), 53.

27 Simon, "Sociétés Coopératives" [Cooperative Societies], 247.

28 Edmond Demolins, "Les Habitations Ouvrières," La Réforme Sociale 1 (1882), 301-2, translated and quoted in Shapiro, "Housing Reform in Paris," 491.

29 See, respectively, Ronny Ambjörnsson, "L' Ouvrier 'rangé'" [The Orderly Worker], Ethnologie Française 21, no. 1 (1991): 67-78; and Jonas, Mulhouse et ses cités ouvrières, 151.

30 Clement, "The 'Unrealizable Chimera,'" 73-74; and Erik de Gier, "Avant-garde Welfare Capitalism Corporate Welfare Work and Enlightened Capitalism in Great Britain, the United States of America, Germany and France (1880-1930)," in Warsaw Forum of Economic Sociology 6, no. 1(11) (2015): 117-29.

31 Joseph J. Ermenc, "Avant-Garde Capitalism in France," The French Review 31, no. 2 (1957): 129.

32 Reports were conducted by Dr. Achille Penot (1843), Dr. Louis René Villermé (1840), and Louis Reybaud (1858). See Jonas, Mulhouse et ses cités ouvrières, 145-55.

33 Ibid., 131

34 Luc Georges and Bernard Jacqué, DiverCité: Dans La Cité Ouvrière de Mulhouse [DiverCity: In the company town of Mulhouse] (Mulhouse: Médiapop, 2014), 58. pacify the masses and to win a favorable reputation for the imperial regime. The industrialists-who were mainly Protestantsalso embarked on grand worker-improvement schemes to portray their self-perceived benevolent attributes for welfare assistance. ${ }^{30}$

These intentions were apparent in the Cité Ouvrière of Mulhouse (see Figure 2). Situated in the Alsatian region of eastern France, close to Switzerland and Germany, Cité Ouvrière was the most exemplary among the French company towns. ${ }^{31}$ It was built between 1853 and 1897 for the workers of the Dollfus, Mieg \& Cie (DMC) textile factory. The project was funded by the Société Mulhousienne des Cités Ouvrières (SOMCO) [Mulhouse Society for Working-class Housing] on the initiative of Jean Dollfus-head of DMC - with contribution by the municipality, and the state (only for the first phase of development). It provided 1,243 low-rise, single-family dwellings with gardens (see Figure 3 ) as a response to workers' poor living conditions. ${ }^{32}$

What distinguished cité ouvrière of Mulhouse from other French schemes were five characteristics: (1) the possibility of access to property, (2) the funding model, (3) the location, (4) the potential for houses to grow over time, and (5) the cultural and social capital it promoted. Primarily, the development model offered the workers the opportunity to purchase a dwelling after a period of thirteen to fifteen years. Mulhousian cité ouvrière represented the first time in the history of social housing that access to property became possible. ${ }^{33}$ It did not target the lower sections of the proletariat because their salaries were not fixed ${ }^{34}$; however, it still differed from other schemes because neither accommodation nor ownership was compulsory for the workers. Also, to preserve its industrial character, SOMCO limited the proprietorship solely to workers. 
Figure 4

Map of the city growth (1200-2015) showing the central location of Cité Ouvrière within the municipal boundaries. Source: Municipality of Mulhouse, edited by Fani Kostourou.

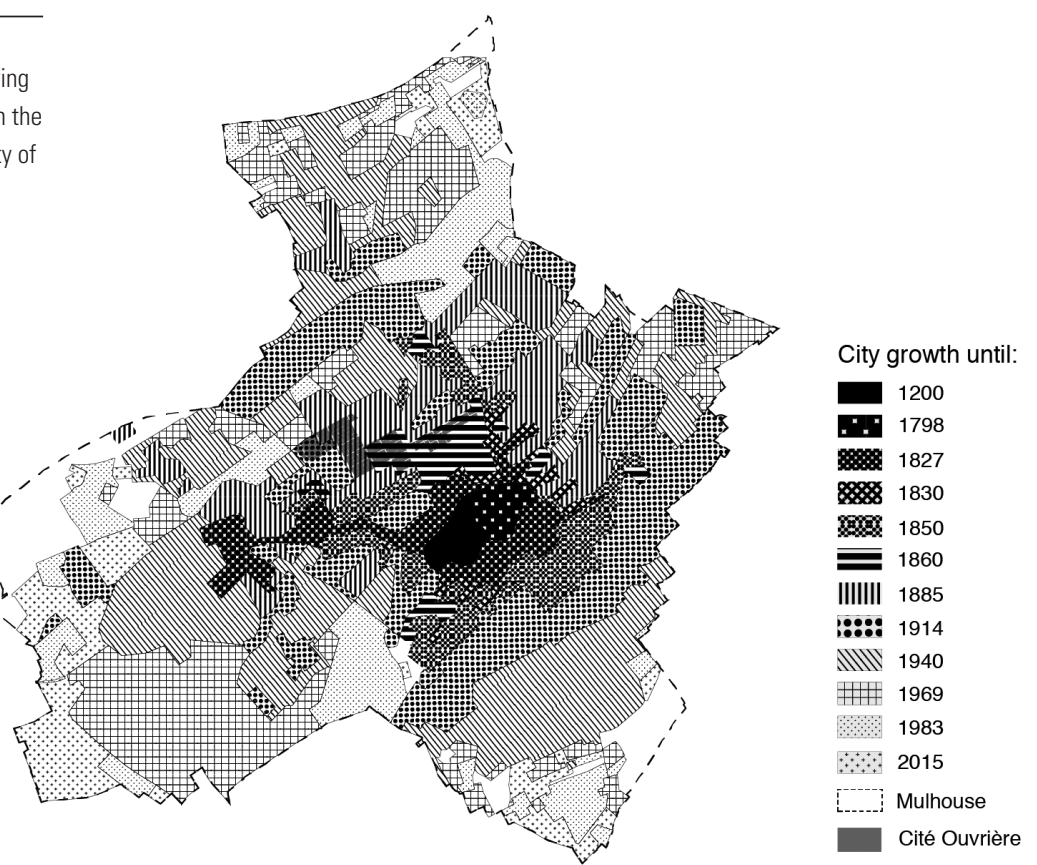

35 In fact, Napoleon promised a subsidy of 300,000 Fr. in 1853 (Garner, The Company Town, 46) but only half of the amount was delivered, and the municipality "saved" the operation by covering the rest.

36 Jonas, Mulhouse et ses cités ouvrières, 131-33, 150.

37 Clement, 84.

38 Jonas, Mulhouse et ses cités ouvrières, 119.

39 For an analysis of Cité Ouvrière's street network, see Fani Kostourou, "Configurational and Morphological Sustainability in Social Housing: The Case of Cité Ouvrière in Mulhouse," in Proceedings of the 10th International Space Syntax Symposium, no. 7 (London: University College London, 2015): 1-20.

40 This adaptability was also possible because of the flexible legislation. See Garyfalia Palaiologou and Fani Kostourou, "Long-Term Challenges in Urban Housing: In the Search for Intersections Between Design and Policy Regulations," in AMPS Conference Publication Series 7. Future Housing: Global Cities and Regional Problems, ed. Kirsten Day (Melbourne: Swinburne University, 2016), 39-58.

41 For SOMCO, the transformations of houses ruptured the urban character of the scheme. They intentionally imposed formal uniformity as a means
In addition, this development was the first outside Paris where the state subsidized a private enterprise, at least at the beginning. The government contributed 150,000 francs to provide for public infrastructure and amenities. ${ }^{35}$ Meanwhile, the entire financial model was based on the "philanthropy of 4 percent," meaning that SOMCO collected only 4 percent interest on the original capital. ${ }^{36}$ Besides, the land on which the Mulhousian cité ouvrière was built was cheap. ${ }^{37}$ It was owned by Jean Dollfus, who granted it to SOMCO at a low price, thus reducing the average cost of houses for workers. ${ }^{38}$

Furthermore, the land was initially located on the northwest edge of the city, next to the DMC factory. However, as Mulhouse expanded in the following decades, its urban fabric embraced the nineteenth-century development, and embedded it well in the city, both on the local level and wider scale. ${ }^{39}$ Effectively, what was once a remote suburban settlement gradually became a central quarter (see Figure 4), which stands in stark contrast to other European company towns.

Still, the most impressive characteristic of the Mulhousian working-class scheme was the adaptive capacity of the houses. ${ }^{40}$ The scheme mainly featured three typologies inspired by British designs (i.e., terraced, back-to-back, and semi-detached), and a fourth quarter-detached type, the French "carré mulhousien." Through the years and despite the disapproval from SOMCO, the inhabitants and owners incrementally expanded their houses, altered the roofs and facades, added sheds, garages, shops, and 
Figure 5

Evolution of a row of carrés mulhousiens houses over a period of 150 years. Source: Fani Kostourou. to differentiate the cité from the rest of the city, and as an essential condition for low-cost industrial housing. Thus, the various modifications represented for them an "aesthetic of the poor." See Jonas, Mulhouse et ses cités ouvrières, 238.

42 Fani Kostourou, "Formal Adaptability: A Discussion of Morphological Changes and their Impact on Density in Low-Rise Mass Housing," in Proceedings of the 11th International Space Syntax Symposium, no. 73 (Lisbon: Instituto Superior Técnico, 2017): 1-19.

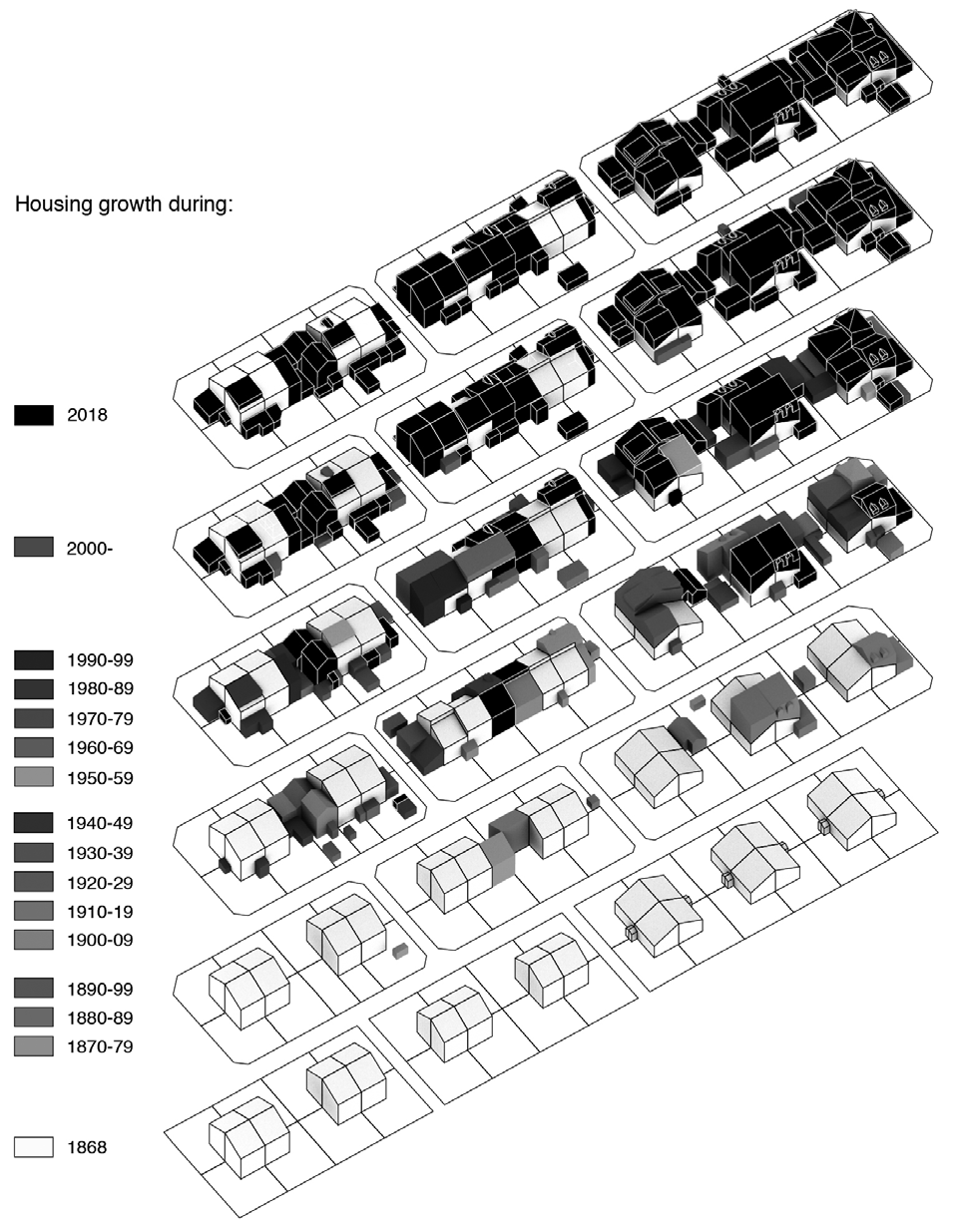

workshops, or rented out parts of their holdings for income (see Figure 5). Although all typologies accommodated extensive modifications ought to the initial low density and generous open space, the carré mulhousien allowed the highest number of interventions because of its spatial configuration within the plot. ${ }^{42}$ Together with the cost-effectiveness of its construction, it soon became the most popular design among the industrialists and the workers.

Eventually, changes made to individual houses and plots created an aggregate effect at the broader scale, which led to the emergence of a plurality of formal outcomes (see Figure 6). The initially uniform and standardized scheme transformed gradually into a spatially diverse quarter as a result of users' participation and design affordance. By affording piecemeal physical changes by the users, the initial typologies encouraged them to invest time, energy, and resources on the locale. In this sense, the design remained socially, economically, and socially relevant in time, while providing an instrument to generate income through subletting and fostering a sense of belonging. 


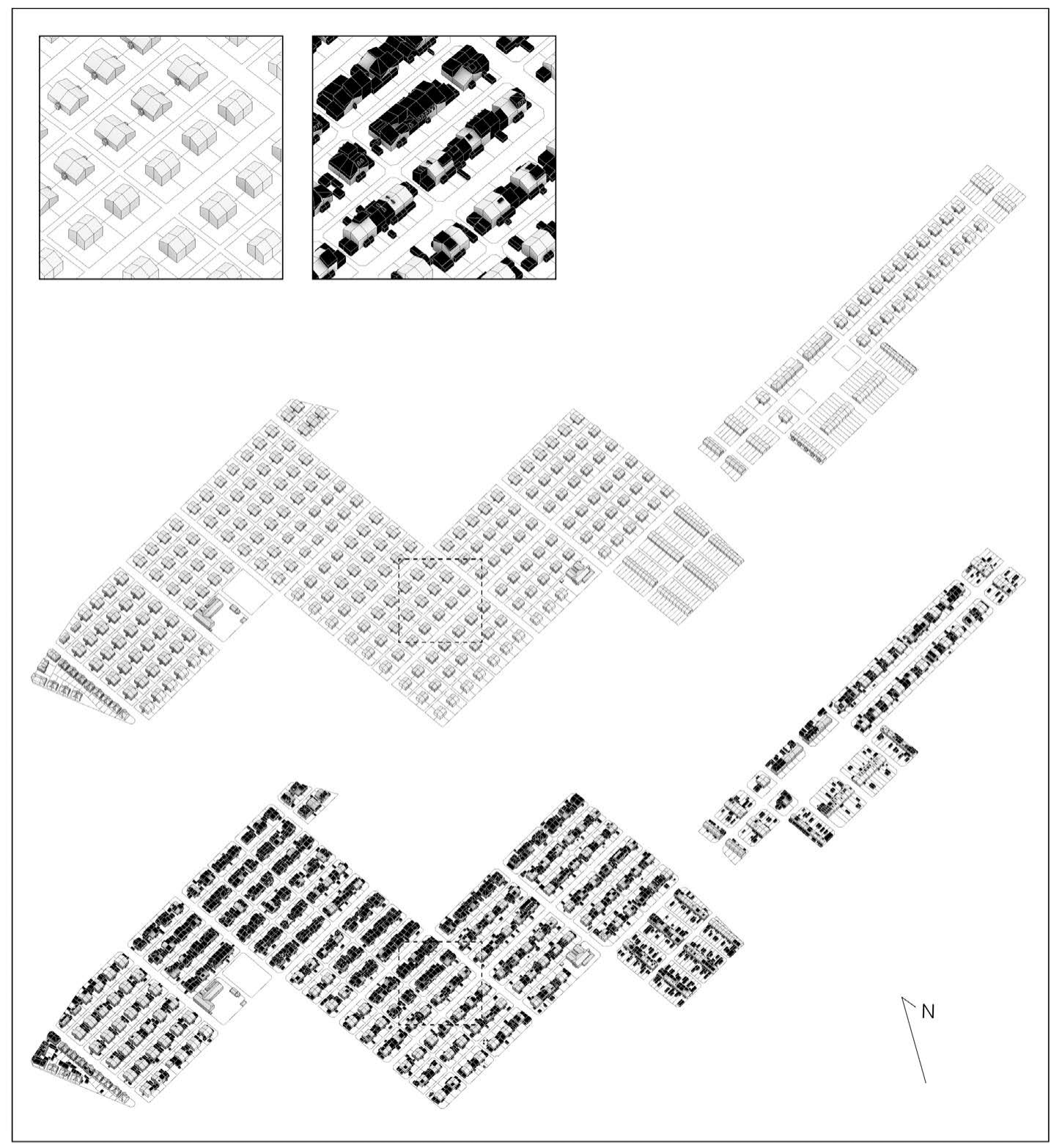

Figure 6

A three-dimensional model of Cité Ouvrière in its original and currently adapted form. Source: Fani Kostourou.
43 Georges and Jacqué, DiverCité, 63.

44 Ray Forrest and Ade Kearns, "Social Cohesion, Social Capital and the Neighbourhood," Urban Studies 38, no. 12 (2001): 2130.
The housing design also created a feeling of neighborliness that had a positive effect on the production and maintenance of social capital in the area. At the beginning, public facilities at the heart of the first development phase of the Mulhousian cité helped to build relationships among the first inhabitants. In 1861 about 150 women would visit the communal laundry each day, and more than 120 people would take a bath. ${ }^{43}$ The neighborhood thus became an extension of the home for domestic activities (see Figure 7) ${ }^{44}$ As these functions slowly moved inside the home and 

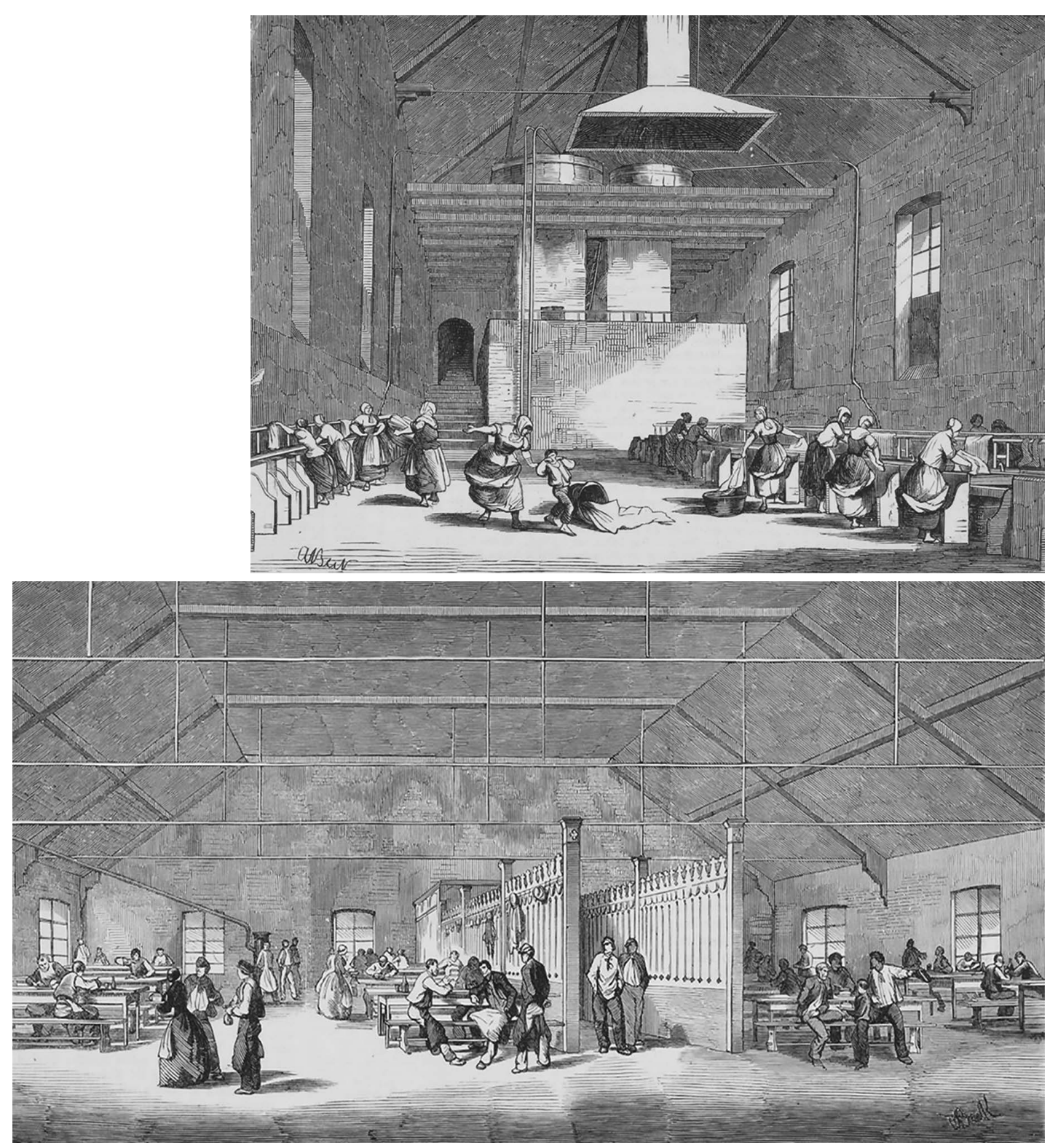

Figure 7

Scenes from daily life in the community laundry (top) and restaurant (bottom). Source: Archives de Mulhouse.

45 Jonas, Mulhouse et ses cités ouvrières, 145.

46 Frédérique Meichler, Sylvie Birot, and Pierre Freyburger, Mulhouse D'ailleurs: Enquête Sur L'immigration Dans La Ville [Mulhouse from else: Immigration Survey In The City] (Mulhouse: Editions du Rhin, 1998), 140

47 lbid., 128.

48 Forrest and Kearns, "Social Cohesion," 2130. public facilities (as well as funding towards them) were reduced in the subsequent expansion phases, the role of the neighborhood changed. Meanwhile, immigrants started to move into the area. Workers from Germany and Switzerland came first, ${ }^{45}$ and later, job seekers arrived from countries like Turkey, Northwest Africa, Italy, and Portugal (see Figure 8). ${ }^{46}$ By the 1960s, the cité ouvrière had become one of the anchor points of immigrants" "residential parkour" in the city, when they had to constantly relocate from one area to another after their arrival in Mulhouse. ${ }^{47}$ In this sense, the neighborhood became a reference arrival point and arena for intercultural encounters, contacts, and associations that enhanced the social capital in terms of identity. ${ }^{48}$ 
Figure 8

Residents and owners of houses in Cité Ouvrière (origin, years of ownership).

a. Madame Musch (Alsace, born in this house);

b. Aubard family (Alsace, 32 years):

c. Erichot family (Martinique, 24 years); d. Madame de Vasconcelos with partner

(Alsace and Martinique, 8 years);

e. Thiam family (Senegal, 18 years);

f. Benhamed family (Algeria, 11 years); g. Marialva family (Portugal, 19 years);

h. Lopez family (Alsace and Spain, 36 years). Source: Luc Georges.
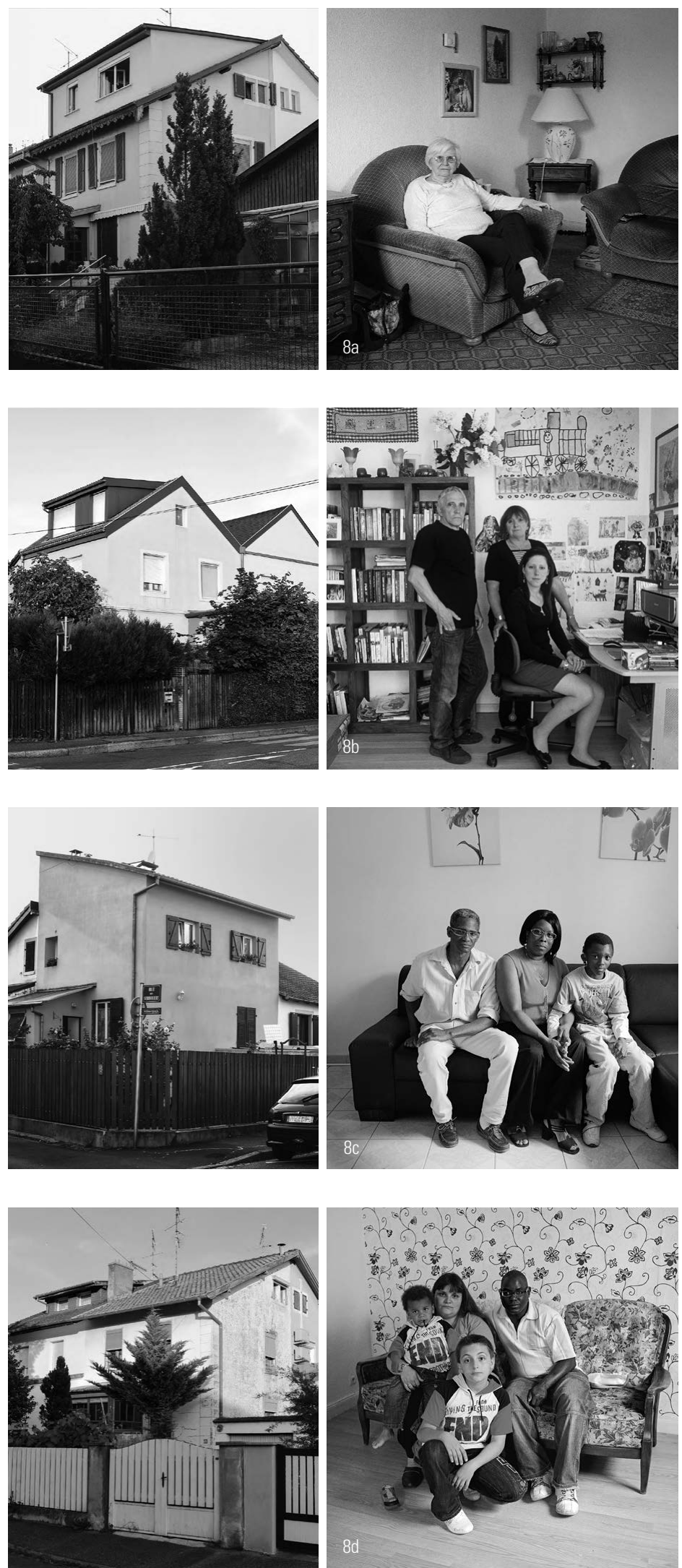

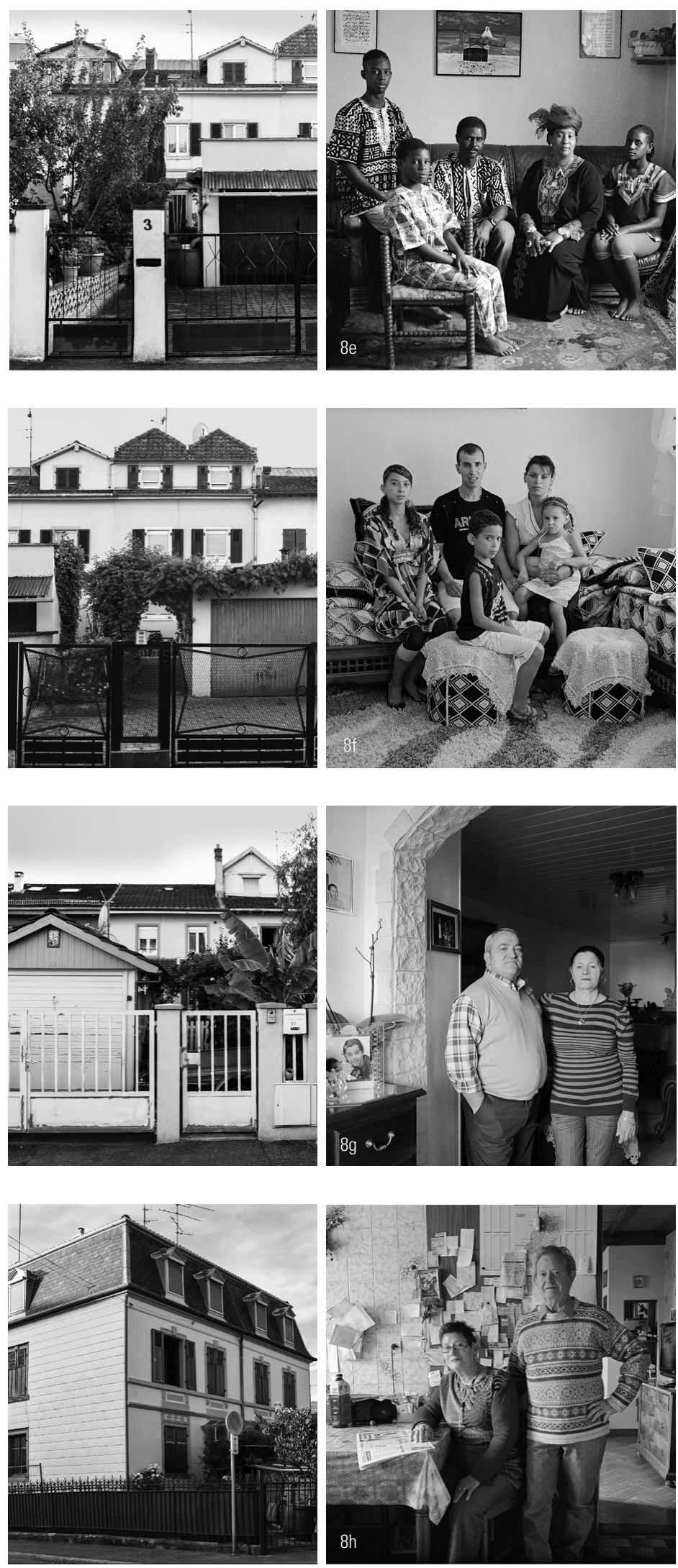

Design/ssues: Volume 35, Number 4 Autumn 2019 


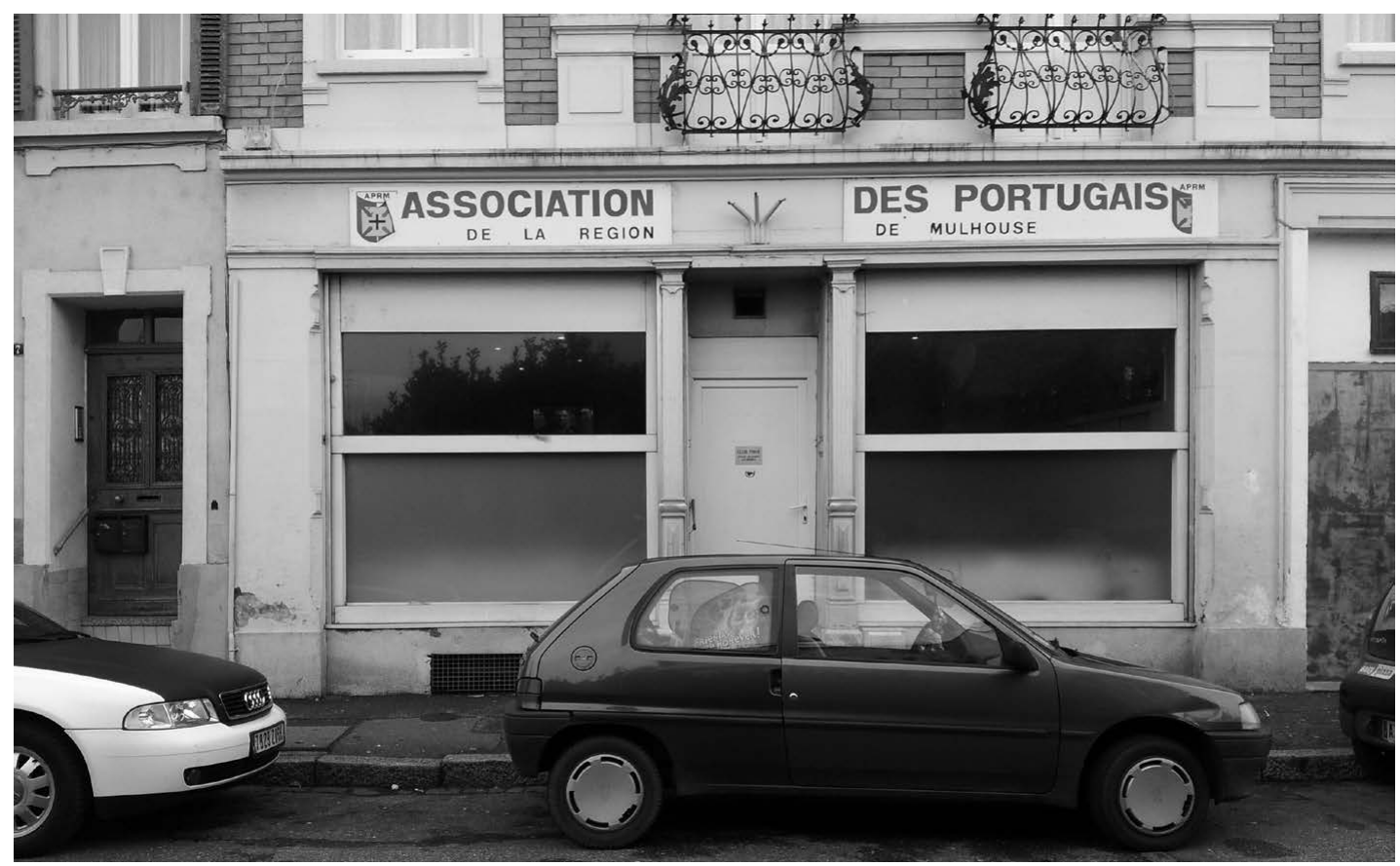

Figure 9

The Portuguese Association in Oiseaux Street in Cité Ouvrière, Mulhouse. Source: Fani Kostourou

49 Fani Kostourou and Kayvan Karimi, "The Intgration of New Social Housing in Existing Urban Schemes: The Case of Cité Manifeste in Mulhouse, France," Urban Morphology 21, no. 1 (2017): 41-60.

50 Ibid., 58.

51 Forrest and Kearns, "Social Cohesion," 2131.

52 See, e.g., Ray Forrest, "Housing and Social Life," in The Sage Handbook of Housing Studies, eds. David F. Clapham, William A. V. Clark, and Kenneth Gibb (London: SAGE Publications Ltd, 2012), 320.
From a socio-spatial point of view, Cité Ouvrière is a simple traditional urban model: street oriented, outward facing, and stranger-friendly.49 Its design "creates beneficial social conditions for a doorstep culture and solidarity among neighbors." ${ }^{50}$ The idea of growing houses implies sites of multi-generation households, which intensifies social practices in space and perpetuates them over time. It also encourages people to live longer in the area and thus to be more likely to develop local friendships. ${ }^{51}$ A study of the municipal archives between 1853 and 2000 indicated that owners of different homes in Cité Ouvrière were often relatives and friends living nearby. In addition, the ethnic heterogeneity helped to diversify interactions, engage defensive communities, and solidify social networks. ${ }^{52}$ For example, socio-cultural associations in the area have included the Association des Portugais (see Figure 9), the Centre Socioculturel Lavoisier-Brustlein, and the Centre Social E Culturel Papin, and their objectives involve social cohesion, integration, and cohabitation. In effect, the design of Cité has to a certain extent influenced the societal disposition of the inhabitants and, by extension, has affected the levels of their community engagement.

\section{From Passive Consumers to Active Participants}

These characteristics of cité ouvrière in Mulhouse support the view that it provides a valuable case study to consider the relationships between housing, home ownership, and social form, as well as the significance of design for the social life in a housing project. 
Cité ouvrière was initiated as a philanthropic act of Protestant reformists to offer sanitary housing to workers. It was not a typical company town, ${ }^{53}$ for it catered for low-cost housing as well as better and more accessible urban planning, community formation through participation to common facilities, and access to property. According to de Gier, it was a comprehensive welfare work model that also provided pensions schemes, mutual aid funds, free medical services, schools, cooperative shops, etc. ${ }^{54}$ Of course, the motives were not merely benevolent. The industrialists also sought to prevent social disorder and increase productivity.

Over the years though, some of the first ideals of the project were compromised, while others were subverted. For example, the provision of public amenities shrunk, and houses became bigger and more expensive so as to allow owners to sublet parts of them. Private property became an instrument to generate profit, allowing workers to move out and to act without any paternalistic interferences. The socially enlightened capitalist approach directed by the Calvinist industrial manufacturers of Mulhouse gave way to a more liberal economic model, where design decisions were made individually by the inhabitants and workers-even if sometimes these were driven more by speculation than utility. This transition became evident aesthetically and spatially, in the urban form of the housing project. The cité changed from a top-down, all-at-once, and monotonous plan to a bottom-up, piecemeal, and formally diverse scheme.

Although both approaches-enlightened capitalism and liberalism-can draw criticism, they both also offer a means to reveal the dynamics of the actors involved in the provision of social factory housing. Based on the Mulhousian case, the bourgeois industrialists had the means to provide solutions to an acute housing problem; nonetheless, their motivation relied on personal gain, and their strategies limited workers' autonomy. Second, the public sector was better at securing public infrastructure and land while ensuring the equal distribution of resources, as well as the integration of foreigners and workers into the social fabric. However, direct commissions for the construction of houses were costly, budgets were meager, and the municipality was reluctant to define longer term reform strategies..$^{55}$ Third, the workers who accessed ownership took an interest in investing both physical capital (houses) and human capital (community) in the area. They took part in common activities, organized community groups, and developed networks within the same or across different ethnic minorities, thus boosting feelings of belonging and identity. They also transformed their houses piecemeal, claiming their right to the housing landscape and advocating for a new and "slow"

53 Garner, The Company Town, 46

54 De Gier, "Avant-garde Welfare Capitalism," 121.

55 Shapiro, Housing the Poor of Paris, 119. 
56 John F. C. Turner, "Mass Housing and User Participation," Built Environment 5, no. 2 (1978-): 91-98. participatory design that has persisted for more than 160 years now. The physical changes were essentially social and spatial expressions of active citizenship and design. They enabled inhabitants to shift from being "passive consumers" of housing goods and services to "active participants" in the aging of their homes and neighborhood. ${ }^{56}$

Hence, other things aside, this particular case denotes a sense of social empowerment by converting imposed ideas into spurred actions. This lesson is particularly important in view of the housing shortage for low-income and displaced populations, who often are excluded from the design and building process. Furthermore, it is a story that needs to be told in times of rising inequalities in the real estate market that challenge architects' role. Historic examples like the cité ouvrière in Mulhouse can inform architects and policy makers of housing alternatives that have been socially, spatially, and economically sustainable and that can help develop responses to the present and future housing questions.

\section{Acknowledgments}

This work is supported by the Engineering and Physical Sciences Research Council [515565]. The author thanks the editors and reviewers for their diligence and thoughtful comments. 